\title{
지진피해 현황 및 지원국회의 개최 계획
}

파키스탄 경제통계부는 지진 발생 20 일이 경과한

10. 28 (금)까지 피해현황 등을 아래와 같이 발표함.

\section{I. 지진피해 현황}

\section{1. 인명 피해}

ㅁ 캐시미르 2 백만 및 북서변경주(NWFP) 130만 등 주민 3.3백만여명이 영향을 받음

미중 10. 28 까지, 사망 55,000 명 이상, 부상 78,881명(캐시미르36,053명, NWFP18,857명)

\section{2. 재산 및 인프라 피해}

캐시미르주

- 학교 3,238개, 대학 1 개, 의료시설 319 개, 경찰 서 등 공공시설 50만 평방feet, 주택 219,000 채, 전력선 $600 \mathrm{~km}$ 및 변전설비 3,000 개, 160 만 명용 물공급시설, 수십 $\mathrm{km}$ 통신라인 등 $\square \mathrm{NWFP}$ 주

$-\mathrm{WB}, \mathrm{ADB}$ 등이 피해 평가 진행 중

\section{3. 긴급 구호물자 추가 소요}

방한용 텐트 35 만동, 모포 2 백만장, 200 개소의 야 전병원, 헬기 40대

\section{4. 복구 및 재건 비용}

ㅁ 40만채의 주거와 보건의료 시설, 학교, 도로 복구 에 50 억불 정도 소요

- 이중 캐시미르주 피해복구에 40억불이 소요(주 거 확보에만 30 억불 소요)

II. 지진 피해 지원국 회의 개최 계획

S. Aziz 총리는 복구지원 확보를 위한 국제 지원 국회의를 11. 19(토) 파키스탄에서 개최할 계획이 
라고 발표함.

- 동 회의에 $\mathrm{UN}$ 사무총장 및 $\mathrm{WB}, \mathrm{ADB}$ 총재 초 청 예정

\section{UN 지원 요청에 대한 각국 지원 동향}

묵제 NGO Oxfam은 지난 10. 26 제네바 개최 지 원국회의 이후 현재까지 각국의 지원동향을 발표 하면서 $\mathrm{OECD}$ 국가중 스페인, 핀란드, 그리스, 오스트리아가 지원에 응하지 않고 있으며, $\mathrm{OPEC}$ 국가들도 UN 지원 요청에 응하지 않고 있다고 발표함.
-Oxfam은 경제규모를 기준으로 비교한 국별 지원 분담비율 비교를 통해 스웨덴만이 $170 \%$ 로 기준을 충족하고, 벨기에( $26 \%)$, 프랑스 $(18.7 \%)$, 일본 $(9.5 \%)$, 미국(6.9\%), 이태리 (5.3\%) 등 대부분의 주요 $\mathrm{OECD}$ 선진국이 기준 의 $1 / 4$ 이하로 기여하고 있다고 발표(파키스탄 언론 인용 보도)

[자료 : 주파키스탄 대사관] 